\title{
PORT CITIES IN A GLOBALISED NETWORK Identifying challenges and visions for the future of maritime hubs
}

\author{
Author: Daniele Blasi \\ Universitat Politécnica de Catalunya \\ Tutor de la investigación: Ferran Sagarra \\ Email: blasi.da@gmail.com
}

\section{RESUMEN}

La complejidad del escenario actual relacionado con el planeamiento, la gobernanza, y las estrategias de proyecto de áreas portuarias necesita un enfoque cada vez más detallado. Los desafíos que enfrentan las ciudades portuarias en el contexto de recesión global y revisión de crecimiento urbano, junto a una visión atenta hacia el desarrollo sostenible, ofrecen la oportunidad de reconsiderar el rol del puerto en áreas urbanas. Una breve reseña de procesos urbanos activados en el ámbito Mediterráneo Meridional durante la última década ayuda a identificar posibles escenarios para la renovación del valor de la infraestructura portuaria no solamente en términos de logística, comercio o turismo. Como las fluctuaciones económicas globales, también evoluciona el rol de la infraestructura, y la tensión que establece con las dinámicas urbanas locales. Soluciones inspiradas por la intermodalidad podrían otorgar al puerto de la era digital las necesarias conexiones globales más allá de las solas dinámicas logísticas.

Palabras clave: Relación Puerto-Ciudad, Planeamiento Territorial, Landscape Urbanism

\begin{abstract}
The complexity of the actual scenario related to planning, governance, and design strategy of large-scale port areas needs a growing detailed focus. The new challenges that port-cities are facing in the context of global recession and revision of urban growth for the years to come, together with a sensible view towards sustainable development, offer the opportunity to reconsider the role of ports in urban areas. A brief review of urban processes activated in the Southern Mediterranean context over the past decade, helps to identify possible scenarios for renewing the economic value of the port infrastructure not only in terms of logistics, trade or tourism. As global economy changes, so does the role of large-scale infrastructure, and its tension with the local dynamics of the city. Solutions inspired by intermodality may offer the digital era port to be globally interconnected beyond the solely logistics dynamics.
\end{abstract}

Keywords: Port-City Relation, Territorial Planning, Landscape Urbanism 


\section{INTRODUCTION, MAIN THEMES AND AIMS}

The research sits in the inter-disciplinary contemporary debate upon the port-city relation in maritime urban centres. The work finds its basis on the observation of the influence of global changes over the city: the instability characterising contemporary global economy pushes towards the reinterpretation of the role of big infrastructural areas within the urban tissue. Specifically, it is evident that the classical economic role played by port-cities has been developing as a system involving the non-linear interaction of multiple factors operating at different scales.

At the same time, it is essential to reconsider the way in which the adaptation to the global economy affects the changes at the local scale of the city. If the direct impact of port-related activities has measured a strong weakening, the presence of large port areas in maritime cities still produces, for logic geographical coexistence, repercussions on the urban compound. At the present stage, localization advantages of the port industry have lost their "urban attraction" - the solid relation with the city's environment - hence the most evident effect of the port infrastructure over the city stands in its land use capacity. The presence of big ports within the city induces the isolation of a big part of the consolidated urban tissue that needs to be reconverted into a space of public domain.

The long-lasting regeneration process of waterfronts started by the late 1980s in the European context, has left many disregarded issues. Administrations have been committed to recover central neglected port areas in order to trigger a beneficial economic process for the city itself. Parallel to that, the disconnection between the industrial port and the city has been ignored, as so the relevant debate on how to manage the interstitial tissue deriving from the separation between two different management entities, operating on the same physical field but responding to divergent economic urges: the city's urban planning department and the autonomous port authority.

Working on these premises, the paper aims to analyse the port-city relation in the Western Mediterranean context, focusing on the highlight of valuable research-for-design characters within a selection of cases witnessing a long-lasting urban regeneration related to the port. The restricted focus on the Mediterranean city is essential to take into account common pre-existent natural conditionings and evince how the shared historical heritage of maritime navigation have come through for a reconsideration of the urban maritime identity.

The selected case studies are the cities of Barcelona, Marseille and Naples. The last one will be analysed with a greater in-depth, on the basis of a multi-scale paradigm in which the port-activity structures the economic field of a metropolitan area in the whole region: on the territorial scale, in fact, the port hub of Naples together with the one of Salerno form an Integrated Port System (Sistema Integrato Portuale, SIP) whose implications on the local scale need an integrated view. The analysis intends to identify a set of evaluative features for the final focus of Salerno port-city, whose urban transformation related to the port is actually witnessing its first measurable results.

How to design the future of port-city relation in such an unstable economic context? Which are the possible visions for respectful functions safeguarding the connection with the public urban domain?

These are some of the questions that the present work will try to debate, with the aim of offering instrumental values to enrich the urban planning in pursuit of a productive exchange between port and city. The result will help to identify a set of theoretical tools and good practices for the design and planning of port areas, adding specificity to the definition of an economically efficient infrastructural development model, more respectful of the identity values of places and the peculiarity of urban maritime landscapes.

\section{SEMANTIC VALUES OF THE PORT-CITY RELATION IN TIME}

Since classical times, urban settlements have been growing alongside the coastline with the aim of benefiting from this strategic position in terms of direct access to goods and commerce. Technology related to navigation made prosperous conditions possible in order for port cities to compete on a global scale on the maritime domain definition. The port infrastructure has traditionally served as an economic engine for cities for three main conditions (Musso, 1995):

- as a primary communication route;

- as a source of natural resources; 
- as a possible site for the development of leisure-related activities (or environmental-related conditions).

The port infrastructure has always represented the meeting point between two divergent realities, merged into one physical entity: the global scale of the commerce network and the local scale of the urbanized areas. This confrontation is what produced the cultural energy of maritime cities and enhanced their capacity to operate on an international network of commerce, much before the digital revolution had done so. In this context, the port infrastructure played a vital and instrumental role (Meyer, 1999): it received global transportation fluxes and exchanged them with the local dynamics of the city, by operating as an intermediary between global and local scale.

The development of trade technologies in maritime transportation, at least until the Industrial era, has been characterised by the coexistence of diverse values of the urban life within the public space of the port. In Meyer's words (1999:28) "the new dimension of modern times [...] allowed public space to fulfil [...] various functions simultaneously: new public space was the place where business could be transacted while the latest news was being discussed, where public administration buildings were located alongside cultural facilities, while traffic flowed through on the way to every conceivable destination."

The privileged condition of embodying different aspects of modern public life started to fade when the improvements made in the technology of transportation lead to a structural change of the port itself. Between the late XVIII and the mid XIX century, the Industrial economic system required the port to act in one step of the production chain as the exchange hub of raw or semi-finished materials.

On an economic level, the application of industrial premises to the city turned out to progressively evict the port centrality in the city. It is generally argued that up to the mid XIX century, a spatial continuity within the city and the port is measurable, with the two entities developing on a parallel pace with great physical integration. Following the specialisation of port-related economies, the osmotic relationship between port and city is fractured by the raising of physical and administrative barriers. This physical segregation progressively eliminated that field of tension that had been characterizing the port-city compound in history.

\section{THE CONTEMPORARY SCENARIO: BETWEEN GLOBAL REINTERPRETATION AND LOCAL ADAPTATION}

\subsection{Dystopic coincidence of port and city: the loss of mutual urban exchange}

The unitization of maritime transportation industry of the 1950s, introduced land use in the port economies. Containerisation started to be effective only with available expansion quays for storage, with two major consequences: the rapid growth of mega port-hubs or the creation of new ports in the outskirts of the city. While in the previous stages of development the success of a port was the result of a number of factors access to markets, productive hinterland and gravitational area, access to social capital, inherent economic capacity for position-related conditions, geographical positioning with relation to the main global traffic routes - the situation radically changed: ports with a larger expansion benefited from the accumulative access of container units, rapidly overcoming all every other features. Despite the geographically convenient position, many strategic port-cities within the Mediterranean area started to experience a strong defunctionalisation and consequent decay. In addition to that, transportation of passengers suffered from a consistent decline produced by the overwhelming advancement in the airplane industry by the late 1960s.

For what concerns the making of the city, the sectorization meant, on a long period, the disappearance of the intermediary character between different scales of port areas. It seems the concept of dystopia could be interpreted as the representative idea of this relationship.

Dystopia, ${ }^{1}$ as reported in the most common sources, has two main acceptations:

- $\quad$ the displacement of an organ or a tissue from its natural location;

- $\quad$ representation of an undesirable future, characterised by a totalitarian and technocratic society.

\footnotetext{
${ }^{1}$ The term was coined by philosopher J. S. Mill, one of the most influential thinkers in the history of liberalism and active political member of the Liberal Party, in one of his parliamentary speeches (1868) to denounce the government's Irish land policy. The word was used to express an antonymous concept to the one of utopia introduced in the Western culture since the XVI century expressing an imaginative nearly perfect community or society.
} 
The first assumption relates to the physical condition. To the extent of urban morphology, it is considerable to assume the anatomic parallelism between the port 'organ' -intrinsic and essential to the functioning of the machine and the entity to which they pertain, their natural location: the city. The port performed the function of structuring organ for the city; the removal from its natural settlement have produced an undesirable scenario connected to the application of technocratic visions to the urban context.

Since the very first years of the 1980s, a general reconsideration of the premises of functional planning within urban studies was to become the starting point of the re-appropriation for many port-cities of their identity.

\subsection{Urban Maritime Identity in the 1980 s - The rediscovery of the urban quay as a public space}

With the growing impact of the global environmental vision and the social changes in action, the city recovers the concept of urban complexity. During the 1980s and 1990s a reinvigorated interest towards maritime cities' urban waterfront re-modulation presumes the reconfiguration of the role of the port infrastructure in the framework of global economic dynamics.

The undelayable confrontation with the social decay that port-cities are experiencing during these years offers the chance to activate a synergic regeneration process of dismissed port soils, with the aim of re-functionalizing them in respect of growing environmental pressures. Starting from the London Docklands and Rotterdam Waterstad in the 1980s, on to Genova in the 1990s, it is absolutely relevant to highlight how those processes focused on the reconstruction of the attractiveness of the city in terms of port-related and port-induced activities. It was simultaneously clear that such a depiction of the maritime front of the cities was soon to be taken on by the tourism industry, which in first instance represented a high demand from the local community in terms of number of jobs created.

Nonetheless, those interventions marked the guidelines for the following years. They aimed at restoring the fundamental long lost relationship between city and port. The coincidence of urban collective destinations, together with housing intervention, commercial and directional functions served to recover the essential character of the ports-cities, the one that had to do with the 'field of tension' (Meyer, 1999) between different actors and forged the essence of public space, with a fresh new reinterpretation based on the critical reading of the contemporary conditions.

\subsection{Beyond the 'Waterfront Renewal' era}

Big part of waterfront regeneration projects from the 1990s on, although, suffered from the lack of structural conditions and fell in the hands of real estate development speculation, due to the high profitability of the centric plots. At the same time, the flourishing economic framework of the 1990s, changed drastically: if realities such as Barcelona, Rotterdam, London, New York witnessed a unique boom of local investment in the past four decades, it is essential to recognise the role that the port economic system plays in contemporary urban ensembles.

Beyond the 'waterfront renewal' era, it is time to trace conclusions of the different episodes and to question the role of the port. New challenges arise from the global crisis and the consequent recession. The new port hub cannot exempt from renovating its role in the urban community, specifically considering the social changes deriving from a rather unstable labour market distribution and the different needs on a local scale.

Specifically, it is there to argue how ports can be the starting factor of a much larger structure and source of sustainable urban growth besides architectural chauvinism and real estate dynamics. Within this renewed context, what is there to understand about the 'waterfront renewal' season?

The specificity of the local impact of global economic networks is essential to understand the space of the contemporary city. Locally speaking, the first great issue to be highlighted is the administrativemanagement condition of the intervention. Generally speaking, we could cast three actors in the play: port authority, city governance and private investors. The legislative framework in which these operate is very different from country to country. It is undeniable that the legislative framework in which the involved actors operate can radically change such a big scale process and that the synergic coincidence of interest is very difficult to be addressed when different decisional entities come to a confrontation.

Furthermore, it is evident how the geographical and historical pre-existences can vary severely the field of action when speaking of waterfront urban projects. In the specific context of the Mediterranean historical portcities, waterfront renewals need to face a series of challenges that present unpredictable archaeological 
relevance, historical compounds and all series of built environment that cannot be torn off but mainly reconverted. In addition to this, Mediterranean coastal port-cities, as previously analysed, are set into a geomorphological condition of tight coincidence between consolidate urban texture, maritime threshold and natural reliefs, so that the freedom of action is strongly reduced to the existing interstitials.

\section{MEDITERRANEAN PORT-CITIES IN TRANSITION}

Resuming the complex implications introduced, we could state that the contemporary depiction of the port-city relation stands in the multiple combinations of the following factors:

- Multi-scale impact (MI): great intercooperative bounds between the local compound and the strategic metropolitan area;

- $\quad$ Public Space (PS): Strong role of the infrastructure in the local community;

- $\quad$ Actors (A): Port Authority, local governance institutions, private investors, local community;

- $\quad$ Pre-existent conditions (PC): territorial geographic and orographic palimpsest.

The methodology used consists of an intentioned analysis, based on the available literature, of a set of case studies within the Southern Mediterranean context. The work suggests, through the critical reinterpretation of the observable processes, the selection of elements that could help to add specificity to the heterogeneous context of the port-city relation. The objective is meant to establish key aspects of the renovation process related to the port activity, whose generally applicable contribution could help to structure the study of a growing number of urban centres. The key factors, derived by the first three case studies, represent a set of instrumental values to be used to evaluate the ongoing transformation process of Salerno city. The process of selecting identification features is one of the final aims of a greater research, of which this work wants to be the first attempt. As reasonable, it will be necessary to progressively adjust the indicators by introducing a greater set of case studies and a structure of acquisitive data, more than bibliographic reference, to which the final investigation is addressed.

The intentional focus over the Western Mediterranean area aims to recover the shared operational context in which port-cities have been developing: it is acknowledged that the Mediterranean has encouraged throughout history the creation of common cultural attributes, essential aspect of such a structural urban intrinsic condition. The reading of the selected case studies will try to highlight the major measurable facts, to try scheduling a table of contents of the analysed processes.

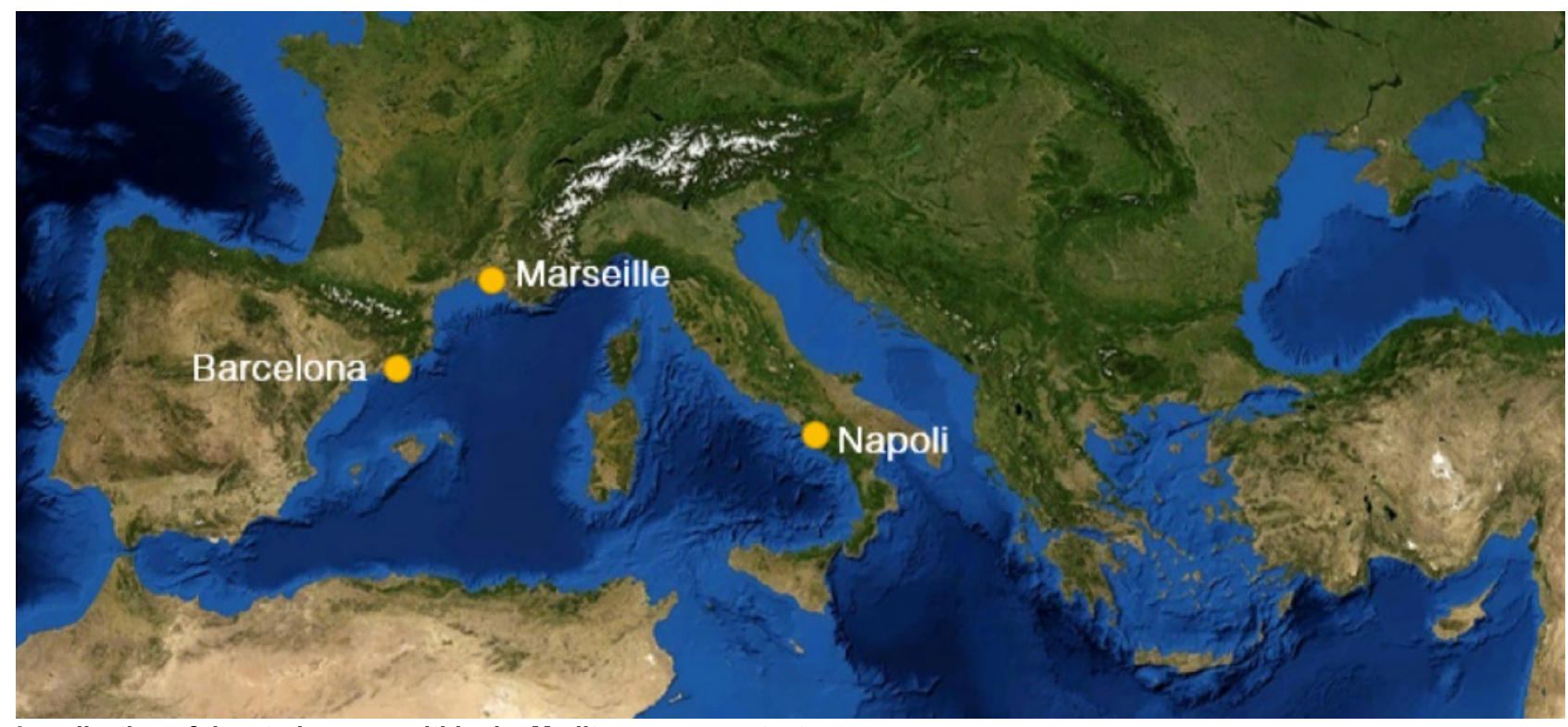

Localization of the study cases within the Mediterranean context

Source: Personal contribution over Google Earth geographical data

Within the Mediterranean area, Barcelona, Marseille and Naples are three of the many coastal port-cities whose urban identity have been transformed by the regeneration processes dealing with their port waterfronts. 
The three great cities, together with their metropolitan area of influence, present an important historical background as strategic port centres on an international scale. The three of them have observed difficulties in the process of renovation of their port areas, highlighting peculiarities influencing to a large extent the results of such big scale transformations.

The common starting point articulates in a way that time conditions the transformation, the design process and the management of the interventions, resulting into extremely divergent realities at the present stage.

A specific focus is dedicated to the case study of Naples and its coastal metropolitan area, including the second major port-city of the region, Salerno. This choice is fundamental to understand the strong interconnection measured on the territorial scale of the Campania region in Italy, which is considered the absolute factor of uniqueness in order to recover the port-city relation on a local and global scale.

\subsection{The project of the contemporary port-city: Barcelona 1980-2004}

The city of Barcelona is one of the best contemporary examples of European coastal metropolis, whose administration has strenuously pursued the reconciliation to its urban maritime identity. Set in the second largest metropolitan area of the country, the port of Barcelona is the third major Spanish hub and figures in the list of the most important European cargo transit clusters. It owes progressively growing success to the exploitation of the cruise passenger terminal, as the city is an absolute stop-by in major intercontinental leisure routes; the port of Barcelona can count on several unit storage quays, as well as a free port zone and more than 200 hectares of industrial bulk (chemical and fluids).

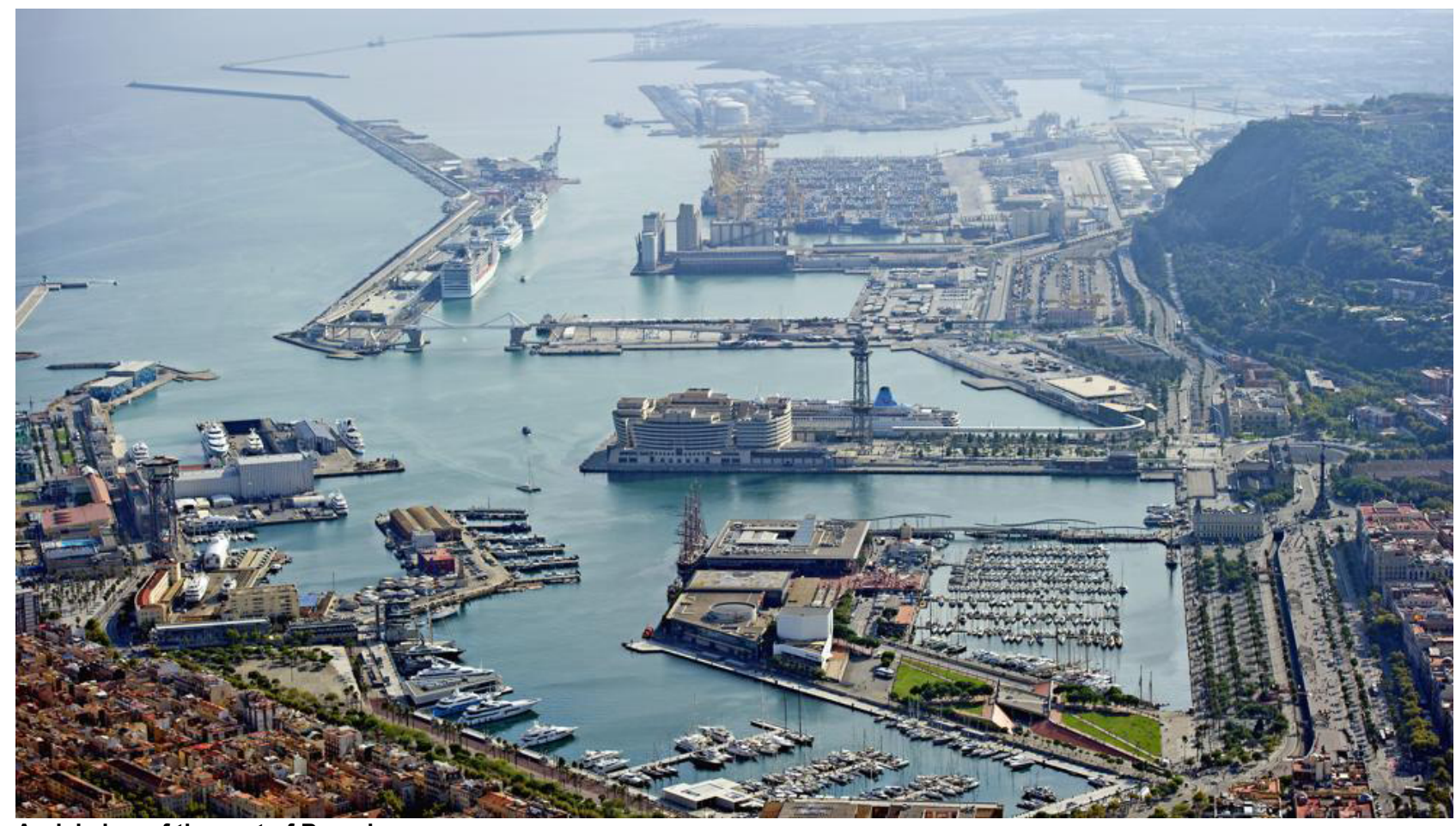

Aerial view of the port of Barcelona

Source: Photography of GARCÍA, Alex.

The actual urban picture of Barcelona is the result of a five centuries-old process of cultural elaboration. It is, indeed, in between the few European cities to hold a constant urban development related to the port presence in the local economy. The port-city relation in the case of Barcelona has not been constantly linear and direct, although a sharp route could be traced to analyse the convergence and divergence of maritime and continental identity. Since the very first decades of the $16^{\text {th }}$ century some very important interventions suggest an urban image strongly connected to the sea. The modern era, however, marks the loss of this vital connection: the forward momentum of the industrial revolution is the chance to affirm an original regional Catalan identity, heading towards continental European spirit (Meyer, 1999), embodied by Cerda's (1859) expansion grid, which definitely inverts the urban gravitational weight from the waterfront towards the North of the city, for the local bourgeois benefit of economic localization (Sagarra, 1996). 
The formal discussion over the relationship between city and port suffers a hold of various decades, just until a set of projects, starting from 1980, transform the historic seafront of the port-city: the urban operations included in the Port Vell reformulation manage to recreate a unique exchange between the old city and the urban port, guaranteeing continuity in the urban texture between the old city and the Barceloneta neighbourhood, and fosters the regeneration impact to the North of the coastal strip, later in time completed with the works for the 1992 Olympic Games and for the Culture Forum of 2004.

The present day scenario is a complex juxtaposition of ambivalent planning activities: the divergence of scopes between the two management entities of the old port areas have compromised a very rich urban process. Alongside the historic waterfront it is hard to recognise today the opening to the sea, beside its constant presence. The continuity of public space in the port-city sector is somehow disregarded by administrative and functional boundaries connected to the introduction of unfortunate vehicle routes and to the exploitation of the Port Vell area for commercial and leisure activities. The physical obstacles of the elevated built volumes withdraws any previous claim for reconstructing an urban maritime landscape, instead causing enclosure of the whole compound. The further destination of some areas to the docking of high standard vessels required the realization of protective fencing which lead to the reconstruction of some sort of anachronistic barriers in what today appears to be the most representative public space of the city. Walking from the historic seafront of the old city, the observed landscape misleads one's perception, just until the maritime condition reveals itself, with its strong scenic presence, in the Barceloneta waterfront, nearly after 2.5 kilometres of walkable pathways.

With the installation of the free port zone to the South of Montjuic, and the destination to logistics of 550 hectares of land, another barrier has been set to the southern sector of the port-city texture: squeezed into the orography of the territory, the Port Autonom entity in charge of the commercial and touristic port of Barcelona since the 1950s - identified in the valleys of the Llobregat river delta its motivation for commercial expansion. The result consists in a progressive loss of the urban scale: moving from the historic waterfront to the south, a strict functional logic orders the territory, proper urban destinations disappear to give room to a complex system of infrastructural fluxes - of both highway and train lines - that runs along the coastline. The truly urban public space is ultimately discontinued by the abrupt impossibility to overcome legally fenced protected areas pertaining to the logistic and transportation hub of the port.

\section{KEY FACTOR \\ DESCRIPTION}

\begin{tabular}{l|l} 
MI & $\begin{array}{l}\text { The port of Barcelona holds a strong beneficial territorial impact over its metropolitan area of influence, } \\
\text { coordinating the market of regional production }\end{array}$ \\
\hline PS & $\begin{array}{l}\text { Central Port Vell has a strong public space potential and a unique attractiveness for both local community and } \\
\text { visitors, although the open landscape has been altered by private investment dynamics }\end{array}$ \\
\hline
\end{tabular}

A The high speculative pressure played against the cooperation between different authorities; there is a great
participation of the local community

PC

Generally plain territory, with singular reliefs such as Montjuic, where now sits the industrial port hub

Analytical table of port-city relation indicators - Barcelona case study

Source: Personal Contribution 


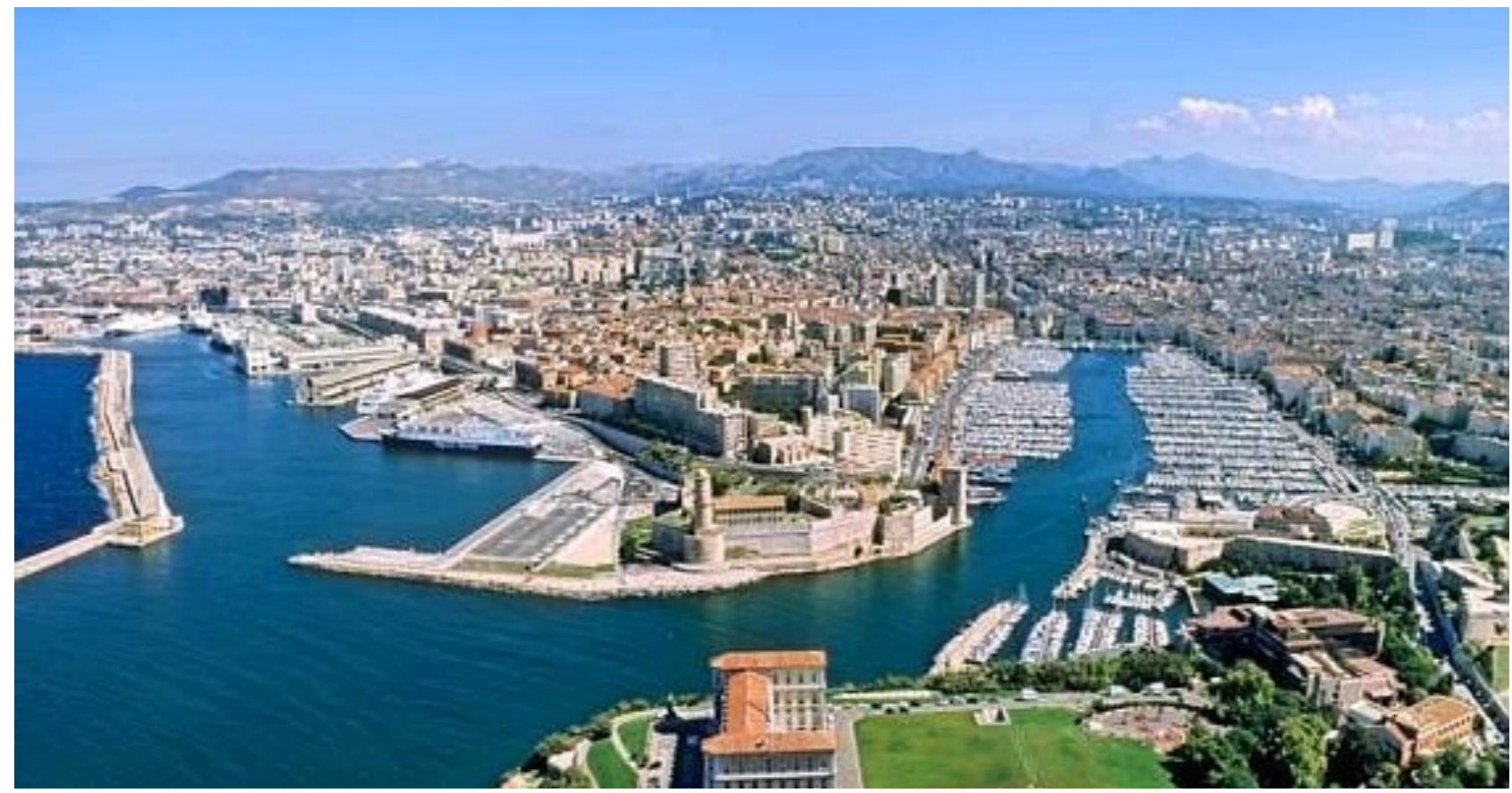

Aerial view of the port of Marseille

Source: DUPLESSY, B. (1992). Marseille vue du ciel. Marseille: Edisud

The city of Marseille is experimenting, at the present day, a very important urban transformation related to the port-city relation. It shares with the previous case study a very important historical heritage of navigation and background related to port activity. The port of Marseille, indeed, has always represent France National State's door to the Mediterranean, and, therefore, to its colonial kingdom of North Africa. Marseille, as the second most populous metropolitan areas of the country, is the most important maritime hub of present day France and one of the major European port clusters. The Grand Port Maritime de Marseille-Fos is structured in two main hubs: the Eastern hub of proper historical Marseille and the Western separate hub of Fos-sur-Mer, established around mid XIX century. The peculiar condition of maritime-fluvial port is what characterizes the success of such a mega-hub, concentrating the main transportation fluxes of central Europe (its gravitational hinterland is extended up to all the Rhenish valley, in direct competition with the Nordic ports). The traffic is also functionally separated between the two basins, so that the consolidated port of Marseille inbound and outbound transit deals only with the Mediterranean routes (Maghreb, Italy, Spain), while Fos deals with all other destinations.

The instrumental value of the case study of Marseille is the way the regeneration process was addressed on a governance level. It shows a functional model of setting patterns of development within established goals to be re-dimensioned in certain periods of time. By the late 1990s, the city was suffering of major crime growth, due a number of factors. The port activity, following the progressive decline of the 1980s, was a great responsible of the urban decay, as it could not guarantee anymore the creation of a considerable number of jobs. The National programme known as the Euroméditerranée project bet on the inversion of the negative trend of the city's economy and the bad reputation it went adding in the past two decades. At the present stage, many of the strategical actions included in the plan of development Euroméditerranée have been completed, and it is surely astonishing how it drastically improved the structure of the city. The reasons for this success can be found both on the administrative setting of the large-scale intervention and on the semantic values of the port it tried to reconvert when it comes to urban life.

For what concerns the proper city design, together with the regeneration of the central inner historical harbour of Roman founding, the programme envisioned Marseille to cover a protagonist role by interpreting the significance of the Mediterranean area, that operationally have taken form of cultural spaces alongside the coastline mixing up with business districts and shopping areas. As observed by Di Palma (2014: 93) "the strategic vision varies, therefore, between the cultural dimension of the exchange in the Mediterranean area and the economic dimension of the international trade".

The specific condition on which it is also interesting to reflect, is the management model activated by the French National Government, for which the programme meant an operation of national relevance. It disposed 
the creation of public management entity, leaded by National Govern representatives, as well as local organizations: the board of administrators within the Euroméditerranée passes the global budgeting and authorizes the funding for the projects according to the local authorities and public institutions involved in the context. The plan still goes on active with the implementation of its second phase, but it demonstrates already a high return for the city in economic and urban terms.

\section{KEY FACTOR}

DESCRIPTION

\begin{tabular}{ll} 
MI & $\begin{array}{l}\text { The port of Marseille holds a strong beneficial territorial impact over its metropolitan area of influence, by } \\
\text { disposing of two different hubs within the same organisation: Marseille and Fos-sur-mer }\end{array}$ \\
\hline PS & $\begin{array}{l}\text { Central Vieux Port has a strong public space potential and a unique attractiveness for both local community and } \\
\text { visitors }\end{array}$ \\
\hline A & $\begin{array}{l}\text { Great integration between state premises of development and coordination with local authorities and } \\
\text { stakeholders }\end{array}$ \\
\hline PC & Generally plain territory, whose port activity is enhanced by the double condition of maritime and fluvial port-city
\end{tabular}

Analytical table of port-city relation indicators - Marseille case study

Source: Personal Contribution

\subsection{Planning over a maritime urban territorial landscape: Campania coastal metropolitan area}

\section{CITTÀ METROPOLITANA DI NAPOLI}

\section{Superficle territorial: $1.171 \mathrm{~km}^{2}$ Población: $3.11 \mathrm{M}$}

\section{PROVINCIA DI SALERNO}

\section{Superflcle territorlal: $4.952 \mathrm{~km}^{2}$}

Población: 1.10 M
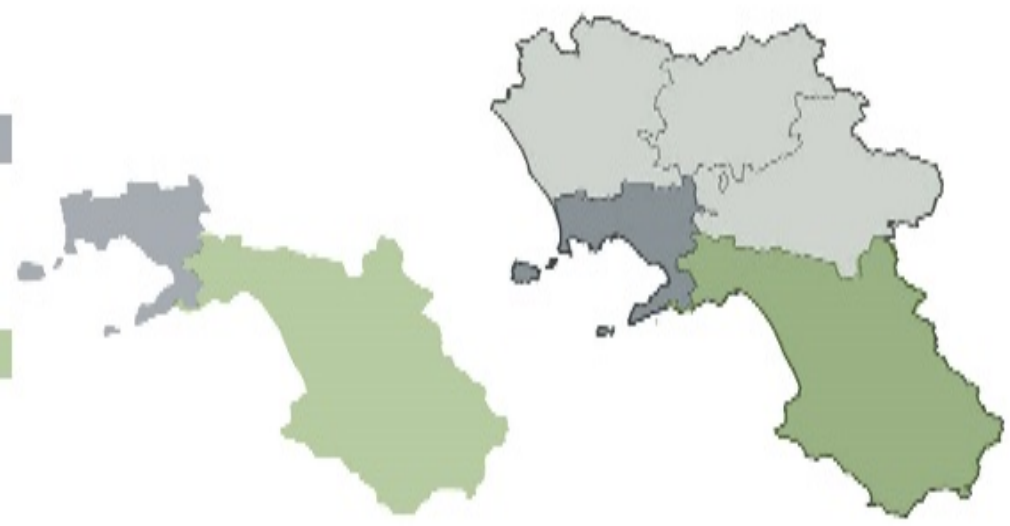

The geographical reference area of Campania region

Source: Personal Contribution over Google Earth geographical data

In order to highlight the major implications of this case study, it is necessary to define the complex territorial port system of the Campania region, in Italy. Convinced that the inner capacity of such a problematic area could get the most out of a renewed territorial vision of cooperation, it is essential to consider a set of aspects pertaining to the definition of the regional planning premises as defined in the Regional Territorial Plan (P.T.R. Campania).

The focus is the metropolitan area included between the two cities of Naples and Salerno, one of the most highly populated conurbations of the country; at the actual stage it suffers from multiple conditionings but it can count on an exceptional number of opportunities: dense historical, cultural, naturalistic and landscape heritage. The urban development in this area of the Campania region presents conditions of structural continuity alongside a coastal strip of more than 250 kilometres long, articulated in two gulfs: the gulf of Naples, capital of the region and the one of Salerno, capital of province and second most important city of the region. The metropolitan maritime area, determined by the continuity of the urban tissue between the two cities, represents the second larger metropolitan area of the country and the first for what concerns population density. 


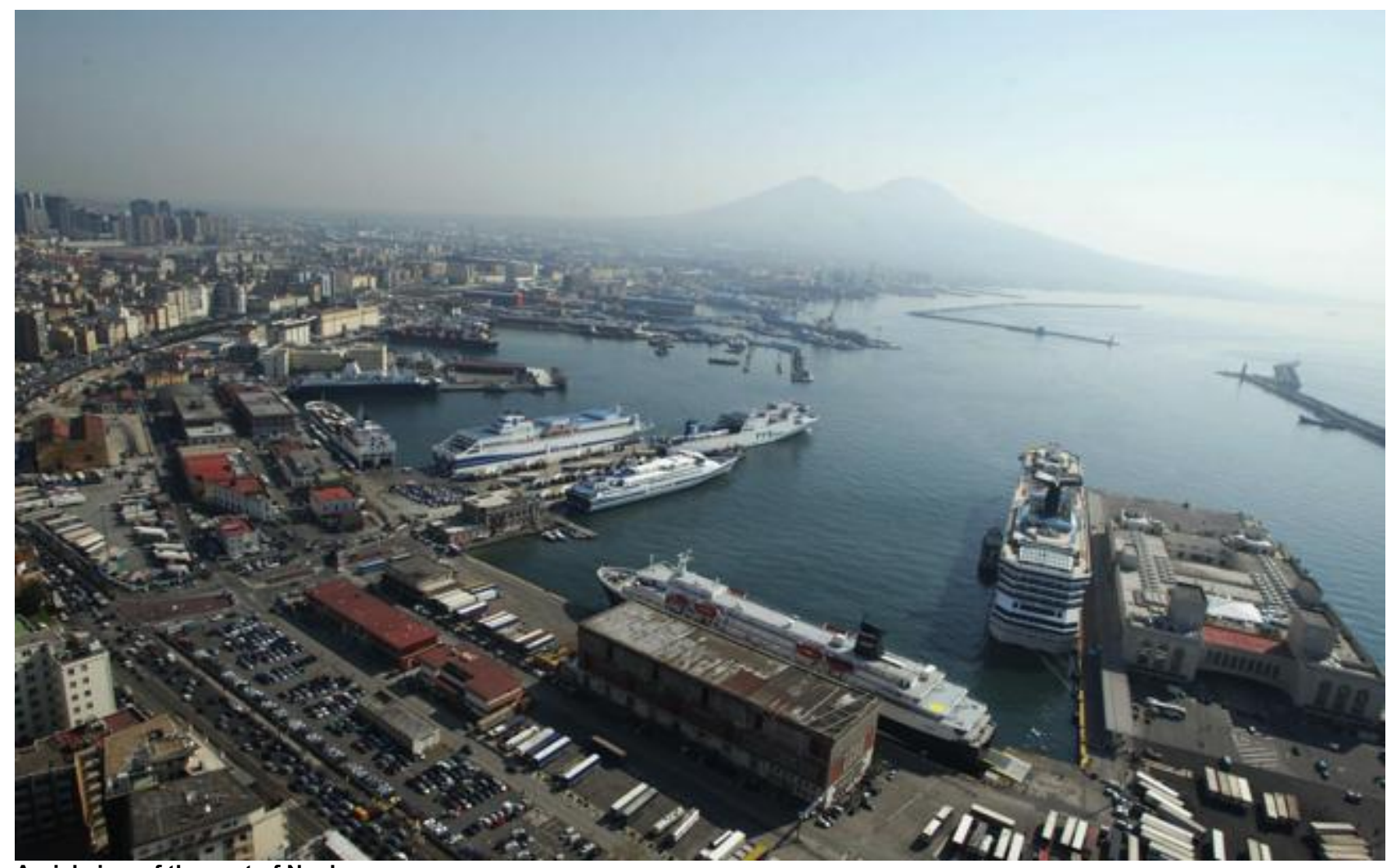

Aerial view of the port of Naples

Source: Medi Telegraph data [http://www.themeditelegraph.com]

At the local scale of the city, Naples started its urban regeneration process related to the refurbishment of its port-city waterfront by the 1970s, with a visionary plan of recovering urban public space of quays through the restructuration of the public transport system. On the other hand, Salerno has witnessed a relatively recent growth but it is focusing the largest part of European funding intervention to its port-city area, which allowed a series of projects to be triggered by the late 1990s. The vision plan for the city of Salerno has one of its strategic lines based on the port: this means that the port area represents a new centrality and that it needs to be open to new urban development. At the local level the port area represents a gravitational pole to which the city has responded with a linear expansion in the opposite direction. The port area represents an unknown territory for much of the citizens, legally segregated from the rest of the city.

At the present day, Naples hasn't completed its process of reconciliation with the port: it represents the paradigmatic case of urban processes conditioned by pre-existences of legislative, archaeological, management and cultural reason, producing a slow acquisition of small bits of success, instead of a structuring re-modulation. Naples and its metropolitan coastal area is the case study representative of a port regeneration process lead in complex environmental systemic conditions.

This study looks forward to tracing the implications of the territory by conducting an analysis at different scale - from the global to the local/territorial one - with the aim of identifying the different inputs influencing the development of a management tool inducing local change in the urban tissue of the two poles.

\subsubsection{The global significance of the territorial system of the Campania region}

The geographical reference area presents a high value at the global scale for it stands on a relevant segment of the crossing between the transnational corridors I and VIII established by the European Commission TEN$\mathrm{T}$ programme. The neural corridor, crossing the whole region, has been reintroduced by the national government as one of the principal premises for revitalizing the entire country's economy. ${ }^{2}$

\footnotetext{
${ }^{2}$ On 24th of Abril, 2016 an accordance agreement signed by the two national and regional administrations foresees the conduction of imperative strategic interventions for the territory.
} 


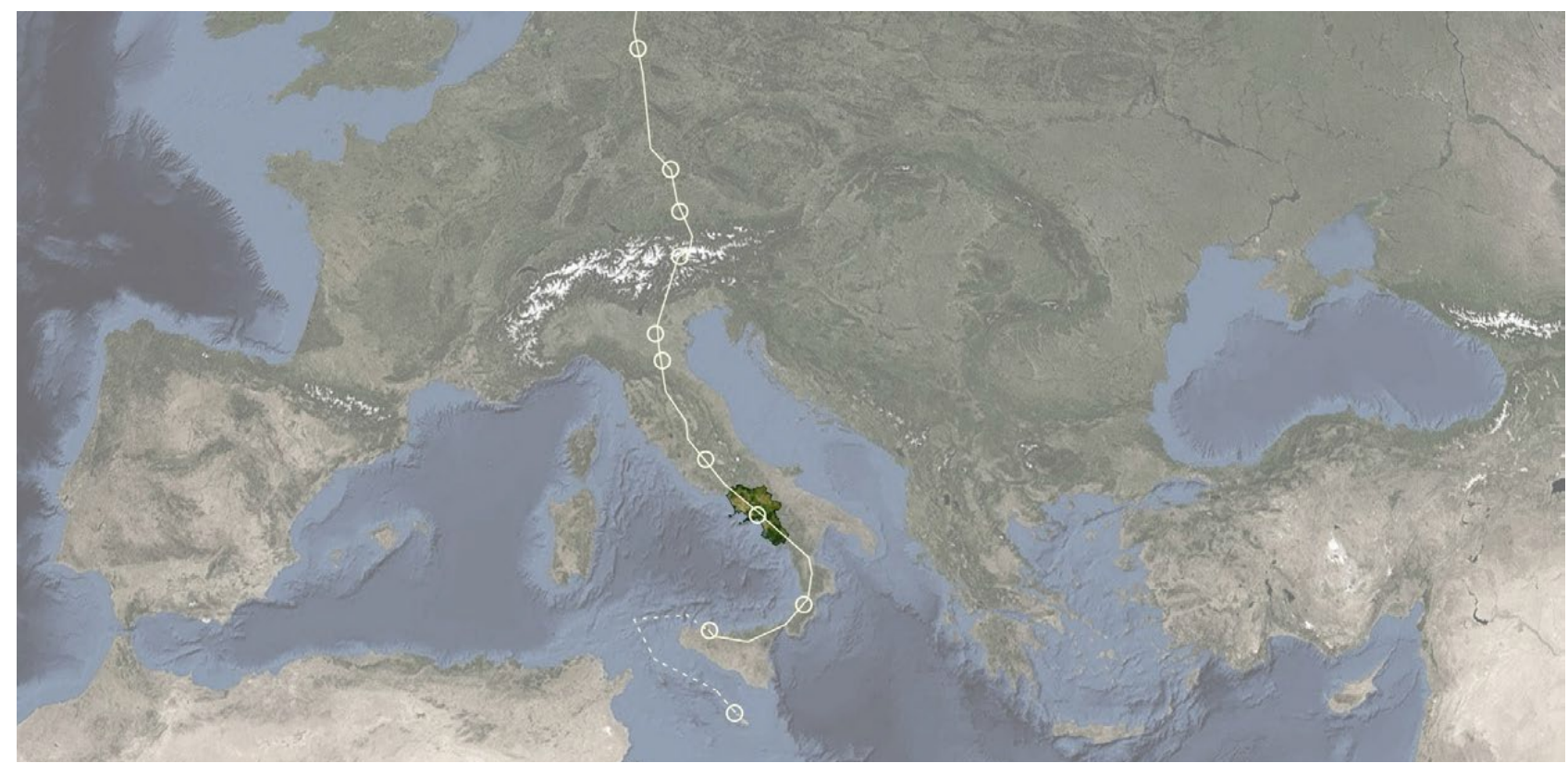

The geographical reference area of Campania region in the European context of Corridor I: Scandinavian-Mediterranean Source: Personal Contribution over data from the European Commission's Mobility and Transport Section

The introduction of transnational and national measures of investment in the context of infrastructural planning highlights a valuable structuring interest at a global scale on the reference area, whose impact on the reconversion of the local system will still produce effects for the years to come. It is evident how the complex operations will modify the fundamental structure of the regional infrastructural system and specifically that the activated interventions will reverberate strongly on the regional port-system.

\subsubsection{The territorial system of port infrastructure of the Campania region}
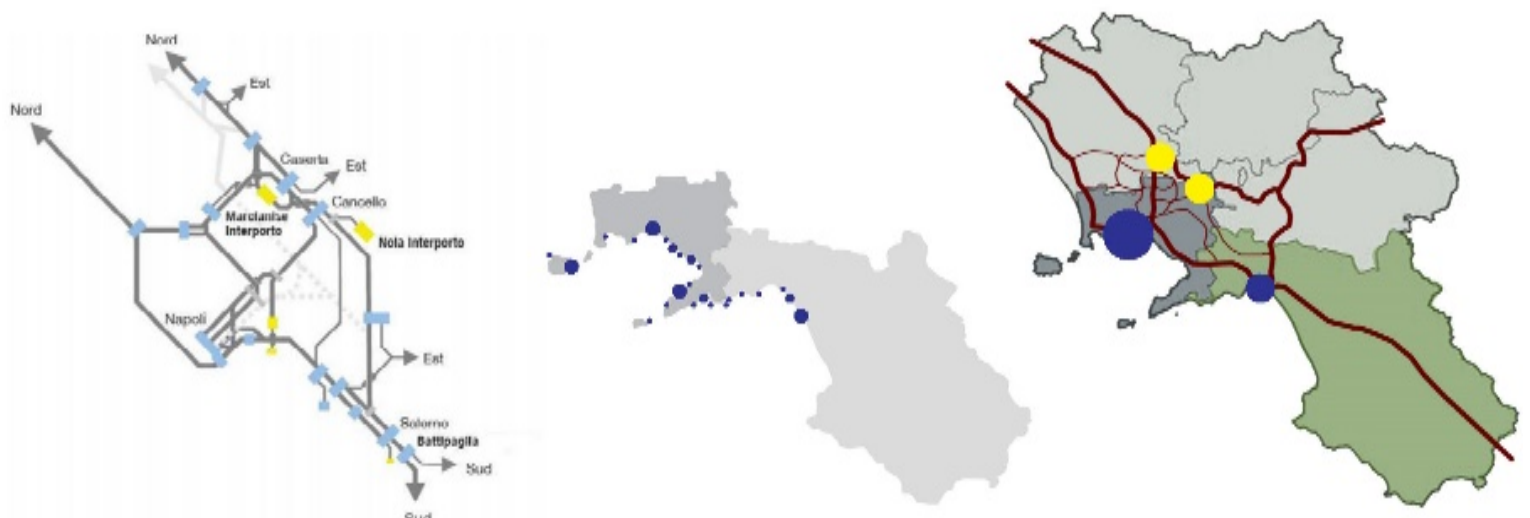

The Regional Port Infrastructure: intermodal connections, nautical ports, regional infrastructure

Source: Personal Contribution over data from the Google Earth

The cities of Naples and Salerno represents, within the regional boundaries, the main urban gravitational hubs. For what concerns the port system, the two cities build together the 'Integrated Port System' (Sistema Integrato Portuale, SIP) included in the list of national relevance. The programmatic previsions (SVIMEZ: 2015) identify as a strategic object of development the enhancement of an ecologic transportation method, in which the navigable maritime ways and the ports play a vital role. Within the regional infrastructural system, the contribution of the maritime transportation considerably increases the attractiveness potential of touristic destinations, awarding them with an additional source of income; at the same time, the integration of the maritime connections system plays a very important role to relieving traffic pressure on the main terrestrial arteries. The ports of Naples and Salerno are the greater commercial ports of the region, both offering a tourist terminal for cruises. The relevant aspect of management is that, although driving totally different traffic volumes (Naples port is significantly more developed than Salerno), over the last decade they have been competing on logistics and passengers, with the hub of Salerno playing a growing attractiveness in the area. On the other side, the cruise passenger terminal of Salerno port, started by 2006, has been measuring annual boosts which 
allowed to witness a growth from 20.000 passengers in 2007 to almost 200.000 in 2015 (Assoporti). Although the numbers are irrelevant to the ones of Naples (2 million passenger in 2016), the number indicates that the strategic interventions activated on the port system is offering the first results, and that the growing importance of Salerno port hub is already translating into a competition on the local market.

The regional previsions of territorial planning included in the P.T.R. highlights, on the one hand, the role of the two ports in cooperating and implementing a management context of logistic traffic at a regional scale of transnational impact. On the other hand, it states the will to benefit from the complex port system (SIP) for the touristic exploitation of the coastal intermodality, "capable of guiding the future of the region towards a sustainable development model for the environment, efficient for the economy and fair for the population of the involved territories" ${ }^{3}$ As so described, the regional SIP acts as a structuring element for the whole metropolitan territory and constitutes the neuralgic system of the regional productive fabric.
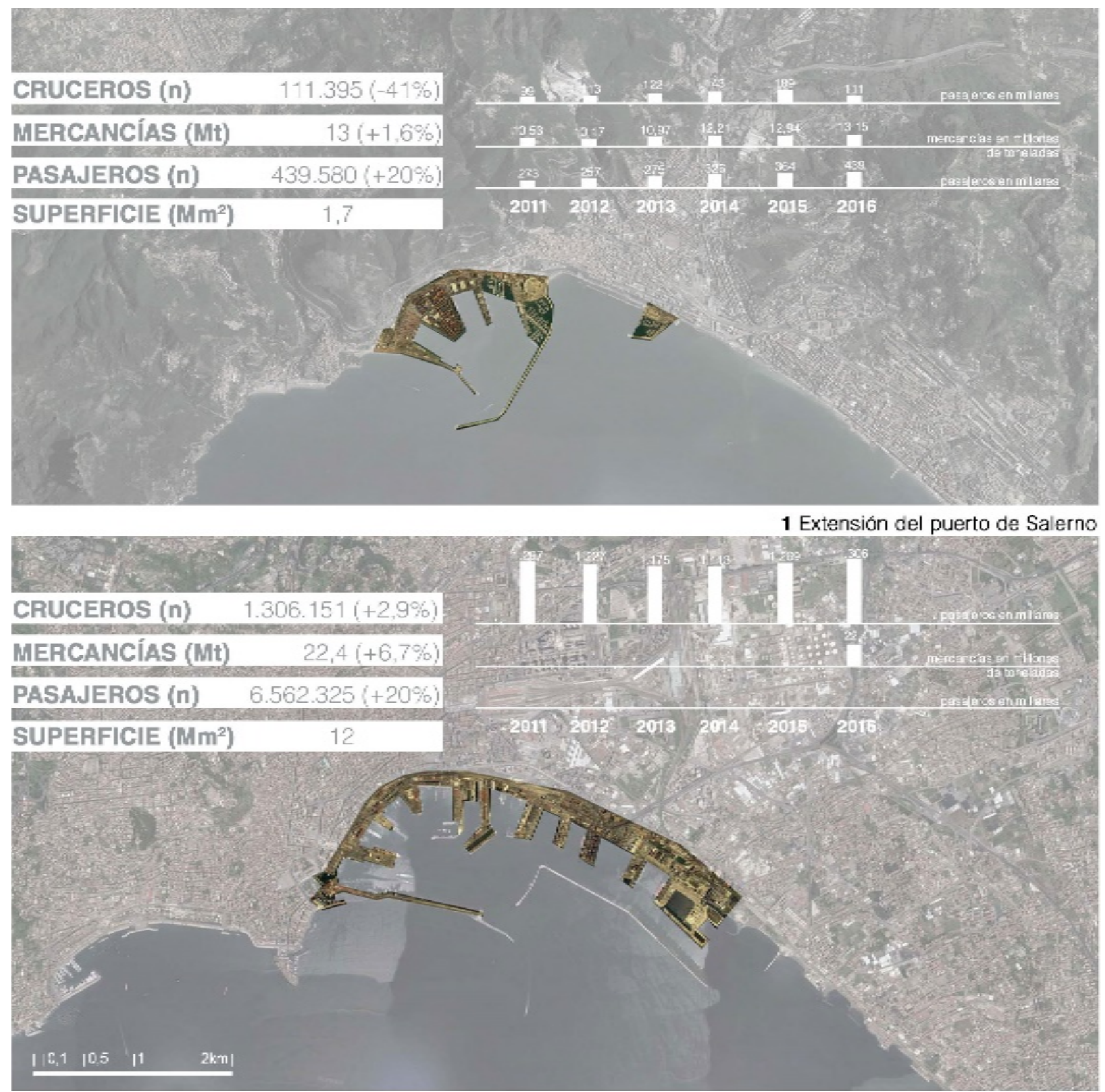

The port of Salerno (top) and the port of Naples (bottom)

Source: Personal Contribution over Google Earth geographical data

\footnotetext{
${ }^{3}$ Translation of the original text: "L'obiettivo generale di settore è la realizzazione di un sistema integrato della portualità turistica e della intermodalità costiera, in grado di orientare il futuro della regione verso un modello di sviluppo sostenibile per l'ambiente, efficiente per l'economia ed equo per le popolazioni ed i territori coinvolti."
} 
A new consideration emerges from the recent law regulations approved in the context of Italy. With the socalled 'Port reformulation' law, the Italian legislation reconfigures, after more than 30 years of legislative deadlock (the past legislation in force dated back to 1984), in fact, single port authorities are grouped into greater regional entities, the 'Port System Authorities' (Autorità di Sistema Portuale, Adsp), in cooperation through a national coordination board managed by the Ministry of Transport, with the final scope of emiting a national logistics planning.

The measurable data from the statistics describe a controversial position of the two seaports, within this renewed legal framework: the hub of Salerno grows by opening its way into more profitable economic niches compared to Naples, reason for which the local operators see as a dangerous attempt the merge of the two entities; on the other side, operators of Naples' hub are more keen to differentiate the services - logistics, shipyards, warehousing - on a market that don't invest Salerno seaport for its lack of adequate infrastructure. There is no doubt a coordination plan could be a safe measure for the sake of the two economies and its global competitiveness; it is still to discuss, though, on what logics the cooperation could be established.

\subsubsection{The urban metropolitan dimension of the Campania region}

The identification of a metropolitan area in the regional boundaries has been an operation of long-lasting definition, characterized by a non-linear process, despite the metropolitanization process was evident since the 1950s. After a set of possible studies and definitions, the metropolitan area is legally approved and defined to be polarized around the city of Naples, extending over an area of $1.171 \mathrm{~km}^{2}$.
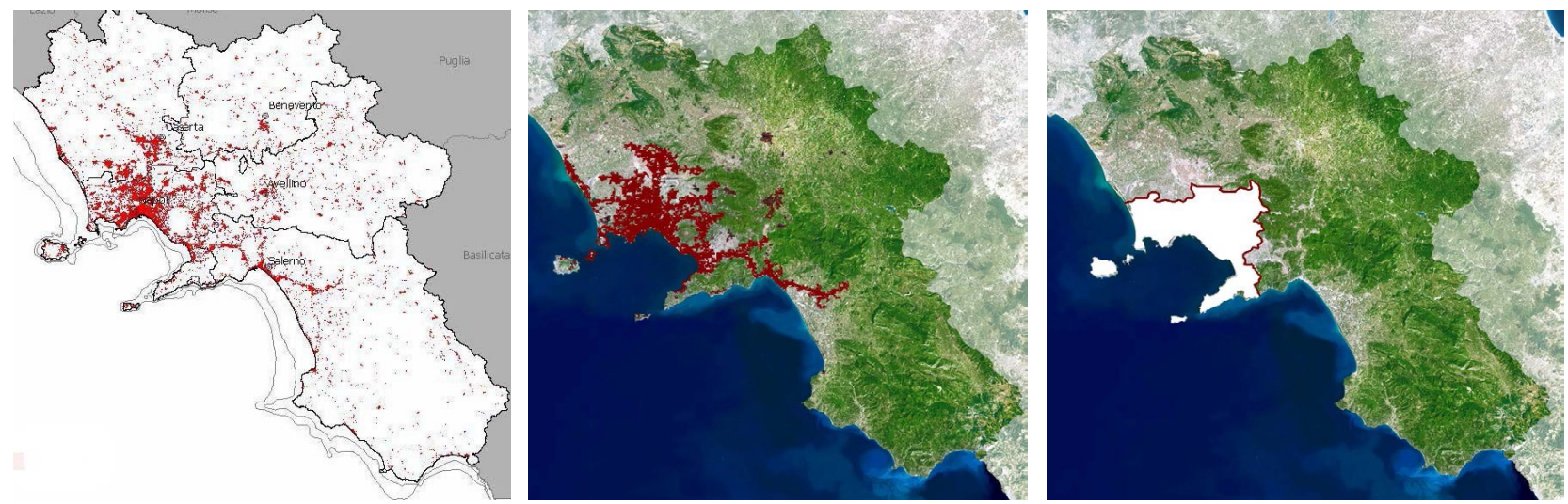

Definition of the urbanized tissue of the Campania region.

Personal Contribution over data from the Regional Territorial Plan and Google Earth satellite image. From left to right: the urbanized tissue within the province delimitations, the same urbanized tissue over the topography and the definition of the metropolitan area of Naples

Following the previously introduced data and the relevance measured in the area of the port system management in the geographical reference context, it is evident how the metropolitan focus could offer different visions of framing the port-city relation on a meso-micro scale, which is to say contemporarily on a territorial and local scale. Regardless the methodology attended for tracing the boundaries of the metropolitan area, an adequate knowledge of the different forces in action underlines the desirable need of an evolution of the same concept of metropolitanization: the definition of the selected case study of the Campania region results anachronistic and, at the same time, corrupted by a set of external conditionings to the context of urban planning. A more respectful approach of the territorial conditions could foresee the identification of a conurbation sharing cultural and immaterial values, as well as economic and functional ones.

With the aim of a correct management of the heritage and the environmental safeguard, and of the optimal consideration of the infrastructural system of the case study, it looks desirable the definition of a coastal interprovincial metropolitan area, encompassing the territories extended alongside the two gulfs of Naples and Salerno. The metropolitan coastal area of Campania region could operate in coordination over a selected set of planning previsions starting by the integrated port system (SIP) already defined. The autonomous management of port authorities doesn't guarantee the global comprehension of the role of the port - nor of an integrated system of ports - in a specific region. Based on these details, it looks necessary to identify a territorial system capable of benefiting from the added value of the maritime traffic when it comes to visual exploitation of the landscape from the sea, privileged perspective made possible by the alternative use of maritime routes. The definition of brand new territorial associations could be capable of editing multidisciplinary strategies extended over a geographic area cooperating for restructuring its urban maritime identity. These considerations lead us to the reflection in favour of two strategic visions: 
- a renewed operational context of port planning forming an integrated and cooperative management system;

- a greater sensibility with respect to the environmental context, both locally (port-city interface) and territorially (port-coastal strips interface and inter-municipal areas).
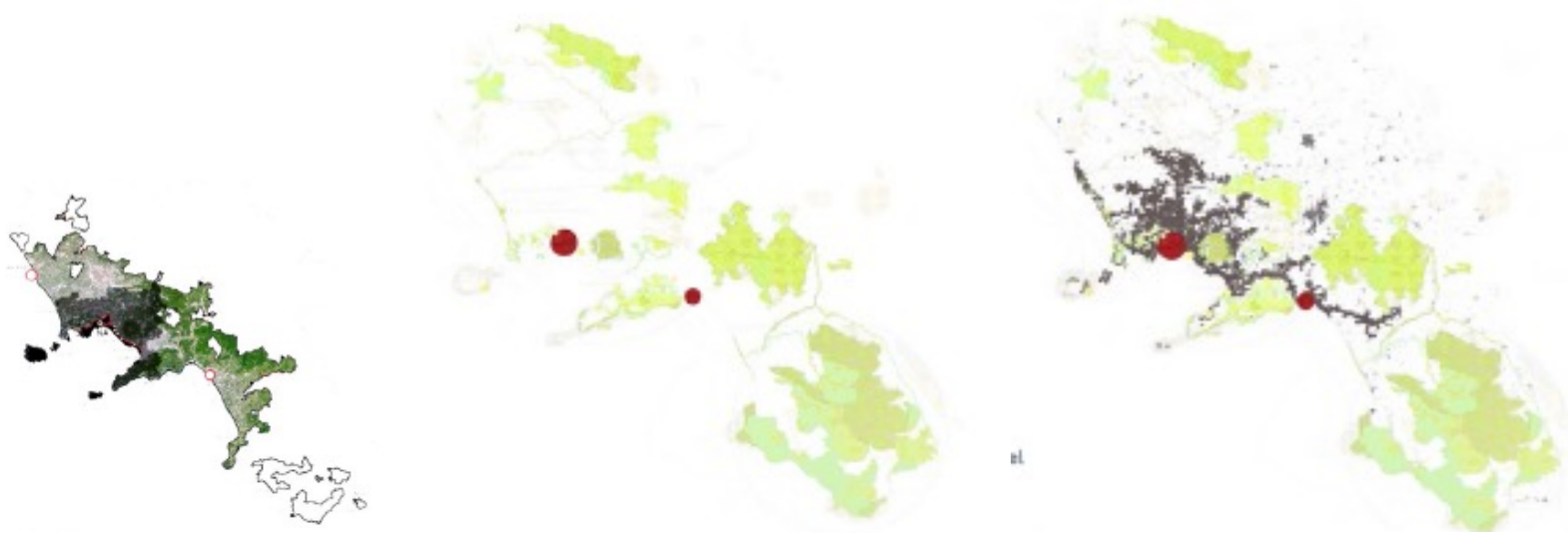

Visions for a coastal maritime metropolitan area

Personal Contribution over data from the Regional Territorial Plan and Google Earth satellite image. From left to right: possible implementation of the coastal metropolitan region (1), the regional environmental palimpsest in the highlighted metropolitan area (2), the urban, infrastructural and environmental layers of the highlighted metropolitan area (3)

\subsubsection{Salerno port-city}

As a final symptomatic case of the introduced premises, explicative of the interaction between local and territorial scale, a deeper insight wants to explore the dynamics of the port-city relation in the city of Salerno, within the metropolitan ensemble already introduced.

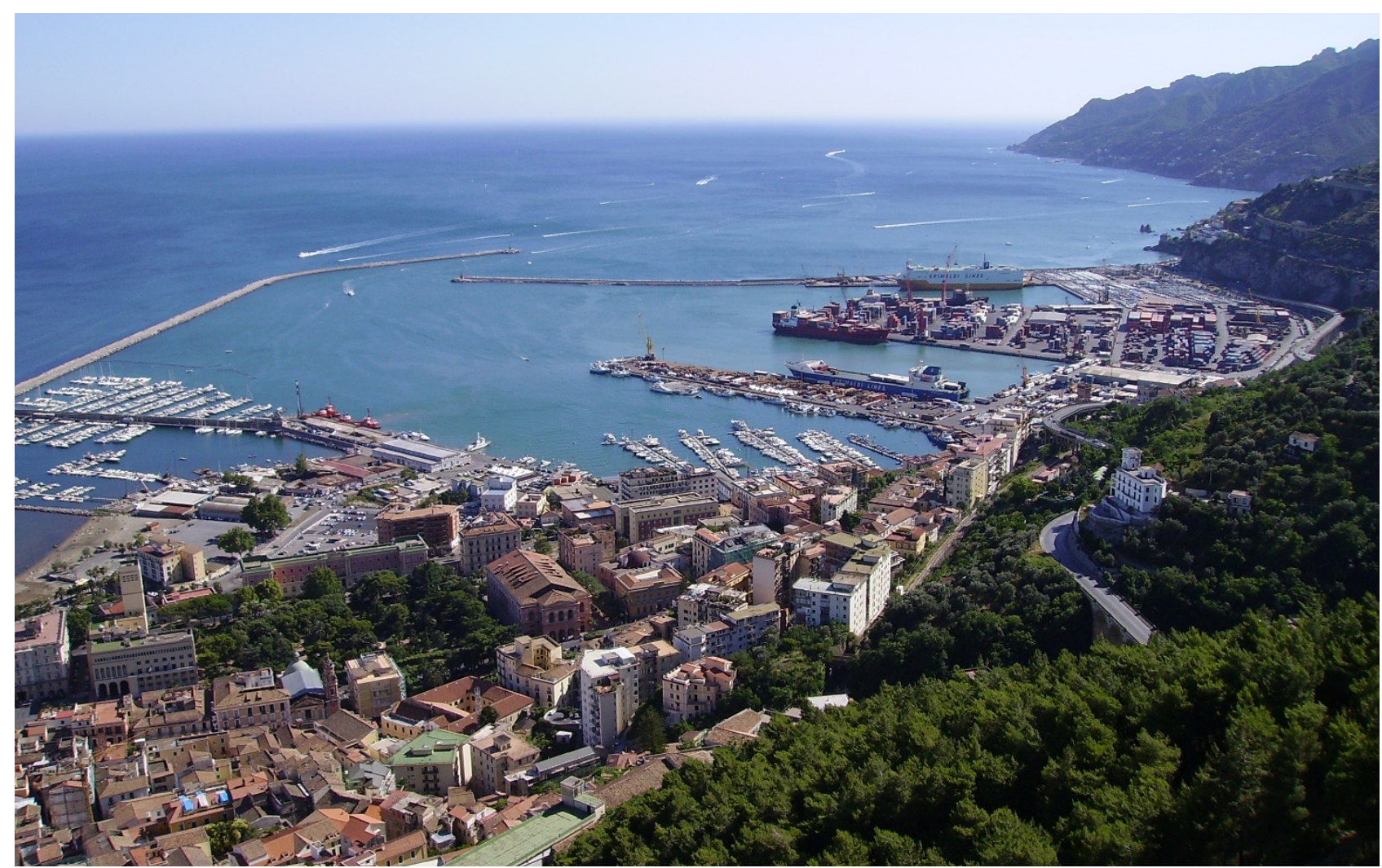

Aerial view of the port of Salerno

Source: Autorità Portuale di Salerno [http://www.porto.salerno.it] 
The bibliographic research highlighted a general scarcity of analytical and critical contributions, reasoned by the relatively recent process of transformation the city have been experiencing. The archive sources resulted likely helpful in order to retrace, besides the ancient origins of the port activity in Salerno dating back to the late XIII century, a controversial development of the port infrastructure, whose consolidation, corresponding to the actual state of the art, happens to be defined only by the late 1970 s and especially thanks to a massive intervention of state financing - just like many other observable coeval initiatives within the European context, typical of a generalised economic growth.

Despite the late consolidation, few strategic documents ${ }^{4}$, urged by a strong decay of the port activity and a general urban degradation, open the way to a new conception of the port-city which will lead to its urban evolution after four decades of uncontrolled growth and scattered densification, together with the reconciliation of the port-city idea, otherwise lost in time. The transformation generated by such planning documents, still ongoing at present stage, are producing their first measurable results, which opens the way to establish preliminary observations of the adopted methodologies and to foresee their development. To the extent of the present work it is essential to analyse the transformation effects, considering the diverse events that affected the urban and port transformation: the growth premises fixed by the previously cited report have been discredited by the economic crisis. Nevertheless, the port activity of Salerno hub, although with a downturn point around 2010, measured a remarkable increase both on passengers' transit and logistics.
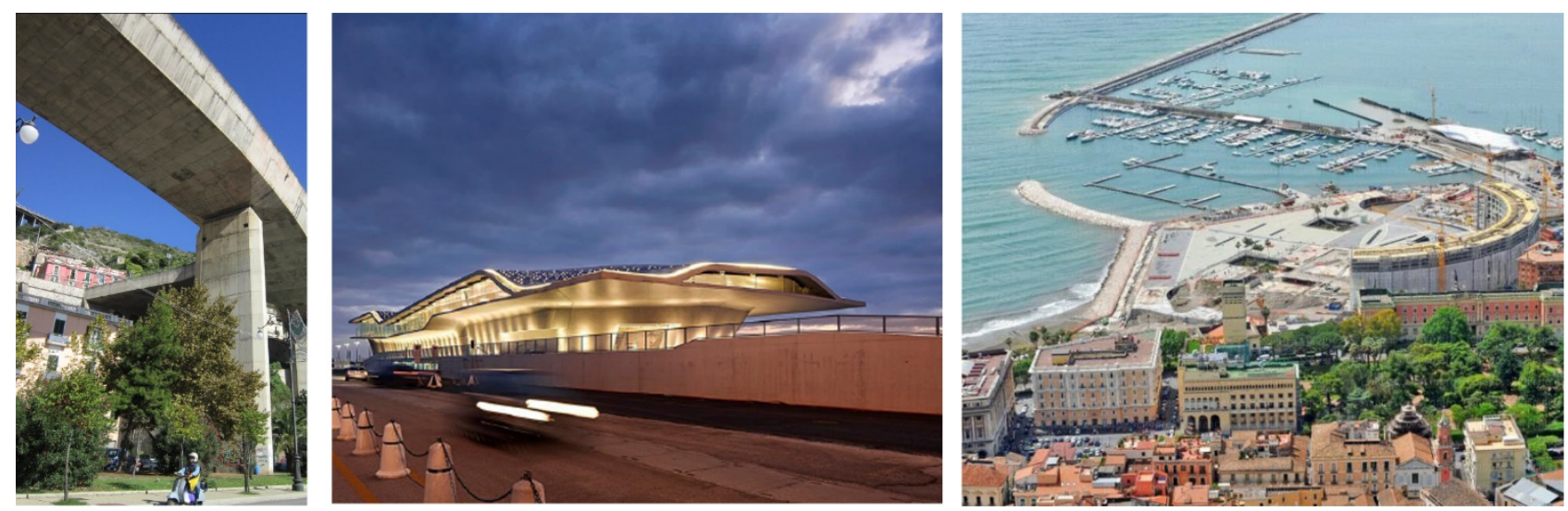

Salerno port-city interface: elevated cargo viaduct, the cruise terminal, high-end residential buildings

Source: Autorità Portuale di Salerno [http://www.porto.salerno.it]

On a parallel side, the urban support presents an employment structure at least uncertain, suffering from a general population decrease. It could be argued that the restructuring of the port activity relative to the solely logistics have not guaranteed the positive outcome of attracting local professionals which is always desirable in such a transformation. Other controversial issues are to be found in the lack of a functional mixite related to the port areas and to the lack of diversification of maritime transportation capable of generating a new regional node.

\section{FUTURE CHALLENGES}

Port cities and, specifically, their maritime-urbanized soil threshold offer today a duality of character: it represents the main strategic challenge to be addressed on an urbanist and governance agenda when facing the placement in the global network, at the same time being the greatest potential for urban clusters to bet on in terms of urban renewal and city's resilient adaptation within mutable economy.

Port infrastructure, as previously analysed, can play a driving role for the city's economy and to the extent of a much larger hinterland, variable in terms of extension not only to its surrounding territory but also within strategic areas - national and international - that take advantage from the specific existence of the port.

When analysing the impact of such an infrastructure, it is frequent to be mislead by the measurable results of the traffic data and its effects on the gravitational metropolitan areas. It is acknowledged, indeed, that similar reflections are pursued for airport hubs in their way to become proper significant urban compounds: in this

\footnotetext{
${ }^{4}$ In first instance the procedural study entitled Salerno città europea: analisi, previsioni per il nuovo piano della città (2000) which will lead to the completion of the Municipal Plan Piano Regolatore Generale 2003 designed by Oriol Bohigas and his catalan firm MBM Arquitectes
} 
context, the hub development passes by the consolidation of the hub as a regional node of interchange, rather than a unique spot of logistics or transportation. Consequently, it is reasonable to think that the same intermodal condition could be the turning point of integration of an infrastructural node at a regional and global scale (Güller Güller, 2003).

By the analysis of the case studies some relevant aspects arose as symptomatic key features of the future of port-city relation, which I will try to resume in the following paragraphs. These aspects are also targeted in order to highlight the scale in which they operate and structure the port-city relation and their interactions.

The attention to the design of public space (local scale with effects on local scale) in interstitial areas pertaining to the maritime port areas, whose definition could be a challenge accomplished by the experience of urban renovation in Barcelona and its strategy of middle-scale strategic design proposals.

The definition of a strategic plan of intervention (territorial scale with effects on territorial/local scale) at a large scale of the port activity, which includes multi-functional management of metropolitan compounds, environmental protection and landscape heritage revalorization: this is an urge strongly revealed by the territorial situation of Campania region, where the port activity itself moves more than half of the economy but is conditioned by a series of key factors.

The definition of an efficient management institution (territorial scale with effects on territorial/local scale), whose representatives could operate at multiple scale of interest and whose previsions could be constantly measured and reconsidered depending on the measurable results, such as the case of the Euroméditerranée project in Marseille. A cooperative port governance entity seems the most reasonable way to go, although variously opposed by the specific economic literature, which instead finds in the free economic activity of single hubs a fruitful aspect of market improvement and port development. It is therefore relevant to implement new management tools for territorial port activity coordination, of interprovincial size. A national scheme, as prescribed by the actual Italian legislation, seems too dispersive and easily disadvantageous, as it would require every seaport to act indistinctively from the extremely varied local conditionings. Speaking of the Italian case, a second critical point seems to be the infrastructural financing, which, according to the applicable legislation should be approved by the national committee, slowing down an already strenuous decisional process. In result to this, it is reasonable to think of an entity organized in:

- $\quad$ an advisory and cooperative committee at the regional scale, of representatives from the regional and municipal administrations, in charge of the economic previsions of the integrated port system, and a differentiation of functional and corporate actions, leaving free activity to the local hubs;

- a technical committee at the local scale, of highly specialized professionals, receiving the regional economic directives with a genuine freedom of planning especially on the urban design and management within the city ${ }^{5}$, with the participation of external investors in order to promote project financing initiatives.

These two entities could edit together the definition of a strategic plan of the urban-port activity, articulating structuring urban previsions related to the port activity, rather than just detailing the works to be completed for the inner functioning of the port (as most of the actuals specialised plans of ports do internationally).

The reformulation of the urban role of the port infrastructure (local scale with effects on local/territorial scale), through the global reconsideration of the port activity and the aim of reconstructing a new quality of urban space, more representative of the contemporary conditions. The possible renewal of the urban functions related to port areas starts by the relevant global economic fluctuations, acting unconditionally on the urban structure. It is desirable to understand a way to react to such an unbalanced state with an alternative structure of functionality in order to support the global hustle, and therefore rebuild a nexus with the urban compound. Specifically, the alternative destination of port areas could be outlined in a set of functional refurbishments, operating in blocks as a parallel system rather than a sequential one: in this system a global input is received and articulated in multiple possible branches, alternatively activating themselves in respect of the actual conditions, avoiding damaging the local chances of development or the emerging of a new set of obsolete areas, unlikely integrated with the urban tissue.

\footnotetext{
${ }^{5}$ A public conference table, such as the one established between Salerno municipality and Salerno Port Authority within the 'Protocollo d'intesa' (protocol agreement) document, holds a strong potential effects on the results of the transformation, although it still represents a prototypical form of coordination to be specialised and implemented on a structural level.
} 
The evidence offers the chance to highlight a set of design strategies that could be considered as structuring functions of port activity alternative to the solely logistics and commercial dynamics. The reformulation of the port-city relation passes by the introduction of a functional mixite within an intermodal maritime-terrestrial transport node of regional relevance. As previously introduced, an urban port capable of holding a strong innovation as all urban structures are asked to in the digital era: a gravitational pole capable of generating innovative services within the directional and logistics apparatus mixed with renewed residential destination not only in terms of building typologies; a desired frame would be one capable of recovering the attractiveness of central port areas while guaranteeing a beneficial irradiance towards the city and its employment structure within a hub of intermodal maritime-terrestrial transport node allowing access to different categories of users.

Undoubtedly, the analysis highlighted that it is essential to recover the semantic value of the port in terms of public domain for the city: this implies the elimination of physical barriers existing between the two entities, the familiarization of the use of the port for the great part of the local community. The activation of such practices as the Port Interpretation Centre (of which numerous examples can be observed in port-cities worldwide), could be an intelligent way to recover the local scale of the port in the city, to promote cultural exchange over an infrastructure most of the times segregated.

The case studies analysed highlighted that possible use could take shape of cultural centres, or places destined to host big cultural events at an international level, whose fruition could guarantee the most varied articulation of users categories: may it be groups of residents or transit passengers, these actions could take in charge the reestablishment of a connection between the different scales of the port and recover its function of cultural catalyst. Contemporarily, it is visible that these actions could induce the partial economic income deriving from port-induced activities, which today are generally developed around the hospitality sector for visitors. 


\section{BIBLIOGRAPHY}

ALEMANY, J., BRUTTOMESSO, R. (2011). The Port City of the XXI Century: New challenges in the relationship between Port and City. Alghero: RETE

AREA D'URBANISME I OBRES PÚBLIQUES (1991), Àrees de nova centralitat. New downtowns in Barcelona, Barcelona: Ajuntament de Barcelona.

BENCARDINO, F. et al. (2010). Turismo e territorio. L'impatto economico e territoriale del turismo in Campania. Milano: FrancoAngeli

BERTONCELLO, B., DUBOIS, J. (2010). Marseille Euroméditerranée - Accélérateur de Métropole. Marseille: Parenthèses.

BOHIGAS, O. (1992). Barcelona: city and architecture 1980-1992. New York: Rizzoli

BRUTTOMESSO, R. (2009). Transformaciones del paisaje portuario contemporáneo: del negocio al ocio...y al negocio, otra vez. Portus 18, 10-15.

BUSQUETS, J. (1992). Evolución del planeamiento urbanístico en los años ochenta en Barcelona. Del plan general metropolitano a la recuperación urbana de la ciudad, Ciudad y Territorio (Barcelona), 93, 31-51

CAFIERO, S. et al. (1981). L'intervento nelle aree metropolitane del Mezzogiorno. Napoli: SVIMEZ

CLEMENTE, M. (2013). Maritime identity and urban regeneration for sustainable development of cities by the sea. Bollettino del Centro Calza Bini (Napoli), 13, 181-194

DE SOLÀ-MORALES, M. (1978). Los ensanches (I): el ensanche de Barcelona. Barcelona: Laboratorio de Urbanismo.

DE SOLÀ-MORALES, M. (1987). La segunda historia del proyecto urbano: otra tradición moderna. UR: urbanismo revista (Barcelona: Laboratorio de Urbanismo), n. 5, 21-27.

DI PALMA, M. (2014). The urban landscape of the port cities: the complex dimension in the evaluation of sustainable development. Bollettino del Centro Calza Bini (Napoli), 14, 85-107

FORTE, C. M., FORTE F. (2011). Porto-città, sondaggi sul futuro possibile: Napoli e la Campania. Portus plus (Venezia:RETE), 1

GHIARA, H., DEMOULIN, P., MARINI, G. (201). Port Center: to develop a renewed port-city relationship by improving a shared port culture. Smart Port-city: essais prospectifs, 3, 233-246

GÜLLER, M., GÜLLER, M. (2003). From airport to airport-city. Barcelona: Gustavo Gili

HOYLE, B.S. (2000) Global and Local Change on the Port-City Waterfront. Geographical Review, 90-3, 395417

KONVITZ, J. W. (1978). Cities and the Sea: Port-City Planning in Early Modern Europe. Baltimore: The Johns Hopkins University Press

MEYER, H. (1999). City and port. Urban planning as a Cultural Venture in London, Barcelona, New York, and Rotterdam: changing relations between public urban space and large-scale infrastructure. Rotterdam: International Books

MUSSO, E. (1996). Città portuali: L'economia e il territorio. Milano: Franco Angeli

SABATÉ B., J. (2004). Patrimonio y Proyecto Territorial. Barcelona: Diputació de Barcelona. 
SAGARRA I TRIAS, F. (1996). Barcelona ciutat de transiciò (1848-1868): el projecte urbà a traves dels treballs de l'arquitecte Miquel Garriga i Roca. Barcelona: Institut d'Estudis Catalans

SMARRAZZO, D. (1999). Documenti e Studi per una definizione dell'area Metropolitana di Napoli. Pianificazione Urbanistica ed Ambientale (Napoli)

SVIMEZ (2016). Rapporto sulla mobilità nell'area napoletana.

WALDHEIM, C. (2006). On Landscape, ecology and other modifiers to urbanism. Topos 71: Landscape Urbanism, 71, 20-24

WALDHEIM, C. (2006). The landscape urbanism reader. New York: Princeton Architectural Press

NORMATIVE AND LEGISLATION

Città Metropolitana di Napoli (2014), approved by Legge Regionale 256 of Abril 7th, 2014

Codice dei Beni Culturali e del Paesaggio (2004), approved by Decreto Legislativo 42/2004 of January 22nd, 2004

Piano Regionale di Sviluppo (1990), Regione Campania

Piano Regolatore Generale (2003), Comune di Salerno - MBM Arquitectes

Piano Regolatore Portuale (2016), Autorità Portuale di Salerno

Piano Strategico per lo sviluppo della città di Salerno (2007), Comune di Salerno - Cer Programació

Piano Territoriale di Coordinamento Provinciale (2012), Provincia di Salerno

Piano Territoriale Regionale (2008), approved by Regional Law no. 13 of October 13th, 2008

Riforma delle Autorità Portuali, approved by Decreto Legislativo 169 of August 4th, 2016

\section{WEB RESOURCES}

http://www.aivp.org (Consulta: 24/11/2016)

http://www.euromediterranee.fr (Consulta: 06/12/2016)

http://www.marseille-port.fr (Consulta: 06/12/2016)

http://www.portdebarcelona.cat (Consulta: 06/12/2016)

http://www.assoporti.it (Consulta: 06/12/2016)

https://ec.europa.eu/transport/themes/infrastructure_en (Consulta: 07/01/2017)

http://www.porto.salerno.it/ (Consulta: 07/03/2017) 